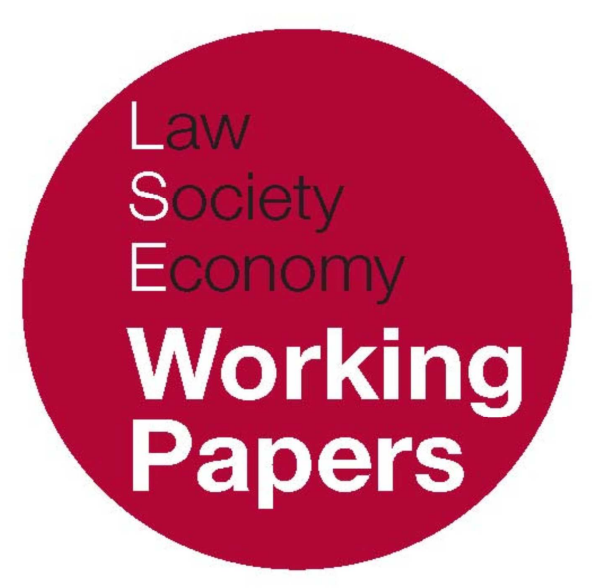

\title{
The Concept of Legitimacy and International Law
}

\author{
C.A. Thomas
}

LSE Law, Society and Economy Working Papers 12/2013

London School of Economics and Political Science

Law Department

This paper can be downloaded without charge from LSE Law, Society and Economy Working Papers at: www.lse.ac.uk/collections/law/wps/wps.htm and the Social Sciences Research Network electronic library at: http://ssrn.com/abstract $=2265503$.

(C) C.A. Thomas. Users may download and/or print one copy to facilitate their private study or for non-commercial research. Users may not engage in further distribution of this material or use it for any profit-making activities or any other form of commercial gain. 


\title{
The Concept of Legitimacy and International Law
}

\author{
C.A. Thomas*
}

\begin{abstract}
In recent decades the term 'legitimacy' has featured heavily in debates about international law and international institutions. Yet the concept of legitimacy, mercurial as it is, has remained under-scrutinised, leading to confusion and misuse. Rather than seeking to advance a particular conception of what may make international law legitimate, this paper seeks to clarify and complicate how international lawyers understand and use legitimacy as a concept. To begin, the paper distinguishes between legal, moral and social legitimacy. It highlights the different ways in which these three approaches to legitimacy have been used in international law scholarship, while drawing attention to some of their more problematic tendencies. From there, it breaks the concept of legitimacy down into three major components: its object, subject and basis. It argues that the tendency to blur these elements has led to much of the uncertainty and obfuscation in legitimacy debates. Finally, the paper considers how legitimacy may be distinguished from coercion, self-interest and habit. Ultimately, it argues that if treated with sufficient rigour, legitimacy provides a useful analytical concept for international lawyers. In doing so, it aims to encourage and facilitate the participation of international lawyers in broader inter-disciplinary debates about legitimacy.
\end{abstract}

\footnotetext{
* Law Department, London School of Economics and Political Science. I would like to thank Lorand Bartels, Hannah Woolaver, Grégoire Webber, Kristen Rundle and Devika Hovell for productive discussions about various aspects of this paper. All errors are mine.
} 


\section{INTRODUCTION}

'It is easier to make certain things legal than to make them legitimate.'

The last century has seen the rapid and unprecedented proliferation of international institutions wielding powers with deeply intrusive implications for the autonomy of states and individuals. States may now be pressured under W'TO rules to change their health or environmental policies; they may be required to align their economies with the policies remotely dictated by the World Bank in exchange for funds; the UN Security Council may impose sanctions that target individuals directly. Although in formal terms these institutions are notionally only capable of performing acts to which states have consented, in substance it is clear that, in many areas, international and transnational institutions have taken on a life of their own.

In the national context, systems of power embodied in law are often subjected to vigilant and demanding scrutiny. In (Western) liberal democracies, this has given rise to a broad consensus concerning the legitimate exercise of power centring on democratic processes, constitutionalism and human rights. Justifications for the exercise of power in the international sphere, however, remain under-explored and under-scrutinised. ${ }^{2}$ Attempts to transfer notions of democracy and constitutionalism from the national to the international and global levels have raised more problems than they have solved. As such, there are presently many active debates about what may constitute the legitimate exercise of power beyond the nation-state. Yet although questions of legitimacy have long been addressed in international relations, political science and philosophy, it is only recently that international lawyers have started to pay the concept much attention. ${ }^{3}$

There are several reasons why the concept of legitimacy has long been neglected in relation to international law. Firstly, it is only comparatively recently that philosophers and social scientists have recognised the relevance of legitimacy

1 'Il est plus facile de légaliser certaines choses que de les légitimer': Nicolas de Chamfort, Maximes et pensées, caractères et anecdotes (1795) 134.

2 Some argue that it does not even receive sufficient attention at the domestic level. Richard Flathman notes that '[m]uch past and present political philosophy either subordinates the question of legitimacy or implicitly treats its possibility and desirability as philosophically and politically unproblematic. It is widely assumed that the politically organized association in which some persons rule others is the divinely, naturally or ontologically ordained state of human affairs': Richard Flathman, 'Legitimacy' in Robert Goodin, Philip Pettit and Thomas Pogge (eds), A Companion to Contemporary Political Pbilosophy (2nd ed, 2007) 678.

3 At the domestic level, US constitutional and administrative law scholars have recently begun to draw directly on insights from the political science literature on legitimacy: see, e.g., Richard H Fallon, Jr, 'Legitimacy and the Constitution' (2005) 118 Harvard Law Review 1787; Frank I Michelman, 'Justice as Fairness, Legitimacy, and the Question of Judicial Review: A Comment' (2004) 72 Fordham Law Review 1407. 
to justifying forms of public power not explicitly based on violence. ${ }^{4}$ International law's traditional lack of coercive sanctions effectively excluded it from earlier investigations. ${ }^{5}$ Secondly, the rapid proliferation of international institutions postWorld War II, and again after the fall of the Berlin Wall, has been accompanied by a historically unprecedented delegation of power to such institutions. This has decoupled the exercise of power at the international level from the will of states, calling for new modes of justification that extend beyond the traditional notion of consent. Thirdly, the potential consequences of breaching international norms have become more serious for those participating in the various international regimes, even as the opportunities to withdraw from or operate outside of them appear to diminish. These consequences have ensured that international law is no longer perceived as something merely technical or as something that just affects 'other people'. 6 Fourthly, the long preoccupation of positivist international legal theory with proving that international law was more than mere positive morality distracted authors from broader questions about why people should comply with international law.

Following the publication of Thomas Franck's seminal work The Power of Legitimacy among Nations in $1990,{ }^{7}$ however, there has been a veritable explosion of scholarship linking legitimacy and international law. This seems apt. The language of legitimacy and the language of crisis have long been associated with each other, standing as they both do at the borders of order and chaos. Following an all-toobrief moment of optimism for international law following the fall of the Berlin Wall, international law has been characterised and shaped by a series of 'crises'. Sometimes international law is posited as the solution to a specific crisis, and sometimes the crisis in question is one suffered by international law itself. ${ }^{8}$ Not

4 Cf, e.g., Christopher Wellman, 'Liberalism, Samaritanism, and Political Legitimacy' (1996) 25 Philosophy and Public Affairs 211, 211: 'Political states coerce those within their territorial borders; if you are in country $\mathrm{X}, \mathrm{X}$ threatens to punish you if you disobey its legal commands. An account of political legitimacy explains why this coercion is permissible'.

5 Although international law and violence are deeply interrelated, they lack the direct formal connection provided by the individual state's monopoly of violence.

6 Mattias Kumm, 'The Legitimacy of International Law: A Constitutionalist Framework of Analysis' (2004) 145 European Journal of International Law 907, 911-12.

7 Thomas M Franck, The Power of Legitimacy Among Nations (1990); Jutta Brunnée and Stephen J Toope, Legitimacy and Legality in International Law (2010); Rüdiger Wolfrum and Volker Röben, Legitimacy in International Law (2008); Lukas H Meyer (ed), Legitimacy, Justice and Public International Law (2009); Hilary Charlesworth and Jean-Marc Coicaud (eds), Fault Lines of International Legitimacy (2010); Steven Wheatley, The Democratic Legitimacy of International Law (2010).

8 Rafael Domingo, 'The Crisis of International Law' (2009) 42(5) V anderbilt Journal of Transnational Law 1543; Hilary Charlesworth, 'International Law: A Discipline of Crisis' (2002) 65 Modern Law Review 377; Wolfgang Friedman, 'United States Policy and the Crisis of International Law' (1965) 59(4) American Journal of International Law 857; Emily Schroeder, 'The Kosovo Crisis: Humanitarian Imperative versus International Law' (2004) 28(1) Fletcher Forum of World Affairs 179; Brian F Havel, 'An International Law Institution in Crisis: Rethinking Permanent Neutrality' (2000) 61(1) Ohio State Law Journal 167; Ronald F Lipp, 'The Crisis in International Trade: Remarks at the 20th Annual McGeorge International Law Symposium' (2002) 15(1) Transnational Lawyer 31; Shirley V Scott, 'Is the Crisis of Climate Change a Crisis for International Law' (2007) 14(1) Australian International Law Journal 31; Francis A Boyle, 'International Law in Time of Crisis: From the Entebbe Raid to the Hostages Convention' (1980) 75 Northwestern University Law Review 769; Michael P Scharf, 'International Law in Crisis: A Qualitative Empirical Contribution to the Compliance Debate’ (2009) 31(1) Cardozo Law Review 45. 
surprisingly, the presence of so much crisis has inspired a great deal of reflection on the legitimacy of international actors, international norms and the international legal system as a whole, ${ }^{9}$ particularly following such events as the NATO bombing of Kosovo, the 'Battle of Seattle' at the 1999 WTO Ministerial Conference and the invasion of Iraq in 2003.

This wave of legitimacy scholarship has prompted a backlash from eminent international lawyers with vantage points as diverse as James Crawford and Martti Koskenniemi. A central criticism relates to legitimacy's semantic ambiguity ${ }^{10}$ and its capacity to be used strategically with little regard for consistency. ${ }^{11}$ Strongly related to this is an assumption of the subjectivity of legitimacy - that, in direct contrast to law, it provides a license to privilege personal moral intuitions at the expense of the system as a whole. ${ }^{12}$ Political actors may call something legitimate or illegitimate not because they have made a considered philosophical reflection on whether that thing aligns strictly with a particular normative framework, but rather because they like or do not like it and are grasping for an authoritative way to express that emotion. Another criticism claims that legitimacy discourse seeks to supplant legal discourse, ${ }^{13}$ a concern that is not entirely unjustified considering the Goldstone report's memorable verdict that the NATO military intervention in Kosovo was 'illegal but legitimate'. ${ }^{14}$ In addition, legitimacy is criticised for lacking

9 See, e.g., A Claire Cutler, 'Critical Reflections on the Westphalian Assumptions of International Law and Organization: A Crisis of Legitimacy' (2001) 27 Review of International Studies 133; Susan D Franck, 'The Legitimacy Crisis in Investment Treaty Arbitration: Privatizing Public International Law through Inconsistent Decisions' (2005) 73(4) Fordham Law Review 1521; Ari Afilalo, 'Towards a Common Law of International Investment: How NAFTA Chapter 11 Panels Should Solve Their Legitimacy Crisis' (2004) 17(2) Georgetown International Environmental Law Review 51; Robert Kagan, 'America's Crisis of Legitimacy' (2004) 83(2) Foreign Affairs 65; Jason Wiener, 'The World Trade Organization's Identity Crisis: Institutional Legitimacy and Growth Potential in the Developing World' (2005) 2(2) Manchester Journal of International Economic Law 54; Manfred Elsig, 'The World Trade Organization's Legitimacy Crisis: What Does the Beast Look Like?' (2007) 41 Journal of World Trade 75; Christine Gray, 'A Crisis of Legitimacy for the UN Collective Security System’ (2007) 56 International and Comparative Law Quarterly 157.

10 "Fairness" and "legitimacy" are mediate words, rhetorically successful only so long as they cannot be pinned down either to formal rules or moral principles': Martti Koskenniemi, 'Miserable Comforters: International Relations as New Natural Law' (2009) 15(3) European Journal of International Relations 395, 409. See also James Crawford, 'The Problems of Legitimacy-Speak' (2004) 98 ASIL Proceedings 271, 271 , referring to its 'fuzziness and indeterminacy'.

11 'In recent discourse there has been very little attempt to use it in a discriminating way': Crawford, above $\mathrm{n} 10,271$.

$12 \mathrm{Ibid}, 271-2$. David Caron argues that "perceptions that a process is "illegitimate" are difficult to describe because they reflect subjective conclusions, perhaps based on unarticulated notions about what is fair and just, or perhaps on a conscious utilitarian assessment of what the process means for oneself: David D Caron, 'The Legitimacy of the Collective Authority of the Security Council' (1993) American Journal of International Law 552, 557.

${ }^{13}$ Crawford describes it as being 'used as a loose substitute for "legality": Crawford, above n 10, 271. Koskenniemi claims that "the vocabulary of "legitimacy" itself tends to turn into a politically suspect claim about the existence of a meta-discourse capable of adjudicating the claims unresolved in its object-discourses, and thus, inaugurating legitimacy experts as a kind of world tribunal': Martti Koskenniemi, From Apology to Utopia: The Structure of International Legal Argument (Reissue, 2005) $591 \mathrm{fn}$ 81.

${ }^{14}$ International Independent Commission on Kosovo, The Kosovo Report: Conflict, International Response, Lessons Learned (2000) 4. 
any meaningful normative content despite its claims to do so. ${ }^{15}$ Finally, Crawford suggests that reflection on legitimacy lies beyond the proper realm of the international lawyer: 'Of legitimacy it is for others to judge'.16

If approached carefully, however, the concept of legitimacy can prove illuminating for international law scholarship and practice. It does not require lawyers to abandon the tools of their trade, but rather calls for reflection on how such tools are to be used. It suggests that, as international lawyers, global actors and human beings, we have a responsibility to reflect on the motivations for our actions and to take responsibility for our role in propagating particular constellations of power and subjugation. Moreover, legal thinking has much to contribute to how legitimacy is understood in other disciplines.

Recognising that international lawyers have begun to deploy the language of legitimacy in increasingly sophisticated ways, this paper seeks to disambiguate the various meanings of legitimacy to facilitate more rigorous treatment of the concept. It seeks not only to clarify, but also to complicate, how legitimacy may be understood by international lawyers. It does not, however, seek to identify what, if anything, makes international law legitimate. As such, it provides an initial conceptual sketch of three ways in which legitimacy is commonly used by international lawyers: the legal, the moral and the social. In each case, it highlights how these different understandings of legitimacy can enrich our understandings of international law's place in the world. It then highlights three elements of legitimacy (its object, subject and basis) that may be used to cut through and contextualise the disparate uses of legitimacy. From there, it seeks to defend the relevance of legitimacy to international law as distinguished from other explanatory frameworks including coercion, self-interest and habit. Ultimately this paper argues that legitimacy is a useful analytical concept for international lawyers, which can have profound practical implications for the reach and application of international law.

\section{DEFINING LEGITIMACY}

Legitimacy has many meanings. It has been deployed by actors at all levels of the international system, from activists to academics, from politicians to the press, from judges to bureaucrats, each of whom ascribe different meanings to the word. Indeed it is not unusual for any given author to use the word multiple times in the one setting while ascribing different meanings to it every time. The plurality of these meanings, and the frequency with which the word itself is used, make it a difficult concept to systematise.

\footnotetext{
15 'Legitimacy is not about normative substance. Its point is to avoid such substance but nonetheless to uphold a semblance of substance': Koskenniemi, 'Miserable Comforters', above n 10, 409.

16 Crawford, above n 10, 273.
} 
To begin, however, Arthur Applbaum helpfully distinguishes between the word legitimacy, the concept of legitimacy and conceptions of legitimacy. ${ }^{17}$ The specific word has been used to denote various ideas across disciplines, time and space. Legitimacy as a concept is a kind of meta-definition that seeks to encompass as many of the different conceptions for legitimacy as possible. The majority of the literature on legitimacy is concerned with particular conceptions of legitimacy associated with some variant of democracy, or justice, or 'good administration' and it is only comparatively recently that the concept of legitimacy has been subjected to more sustained attention.

The confusion over these three senses of 'legitimacy' may in part account for the backlash that the investigation of legitimacy has inspired in some quarters. In a 1990 review of Franck's The Power of Legitimacy among Nations, Koskenniemi dismissed legitimacy as a 'recent innovation' for which 'the classics' — including Hobbes, Locke, Rousseau and Marx — had no use. ${ }^{18}$ This criticism, however, can only apply to the word 'legitimacy', or to the very specific way it has been used in some recent debates. Shane Mulligan points out that the word is absent from Locke's Second Treatise, Hume's Enquiry, Smith's Wealth of Nations and Paine's Rights of Man - yet these works may all be described as centrally concerned with various forms of legitimacy as it is understood today. ${ }^{19}$ Applbaum's research suggests that the 'evaluative'/moral sense of 'legitimate government' (as conceptually distinct from lawful government) materialised in France only in the late $16^{\text {th }}$ century. ${ }^{20}$ Mulligan notes that it did not make its way into England until sometime later, in writings seeking to account for the political phenomenon of Napoleon. ${ }^{21}$ As for international law, it seems the word first achieved prominence with Talleyrand's 'principle of legitimacy' at the Congress of Vienna (although this was more a political principle than a principle of law). ${ }^{22}$

There are several core understandings of the concept of legitimacy in academic writing. Most of the writing on legitimacy from the last several decades distinguishes between two main legitimacy categories. These categories are often allocated different labels, but the functional distinction is similar in each case.

17 Arthur Isak Applbaum, 'Legitimacy in a Bastard Kingdom' (2004) Center for Public Leadership Working Paper 04-05, available at <http://dspace.mit.edu/handle/1721.1/55927> 76.

${ }^{18}$ Martti Koskenniemi, 'Book Review: The Power of Legitimacy among Nations' (1992) 86 American Journal of International Law 175, 175. Cf 'Legitimacy is one of the oldest problems in the intellectual history of Western civilization': Morris Zelditch, Jr, 'Theories of Legitimacy' in John T Jost and Brenda Major (eds), The Psychology of Legitimacy: Emerging Perspectives on Ideology, Justice, and Intergroup Relations (2001) 33, 33.

19 Shane P Mulligan, 'The Uses of Legitimacy in International Relations' (2005) 34(2) Millennium 349, 359-60.

20 Applbaum, above n 17, 82.

${ }^{21}$ See Mulligan, above n 19, 361, citing Stuart Semmel, 'British Radicals and "Legitimacy": Napoleon in the Mirror of History' (2000) 167 Past and Present 140.

${ }^{22}$ For more on the principle of legitimacy in this context, see Stefan Talmon, Recognition of Governments in International Law: With Particular Reference to Governments in Exile (2001) 54. 
Thus distinctions are drawn between normative and sociological legitimacy;23 between normative and empirical legitimacy; ${ }^{24}$ between de jure and de facto legitimacy; ${ }^{25}$ and between moral and descriptive legitimacy. ${ }^{26}$ Some writers add a distinct category of legal or formal legitimacy to the mix..27 Joseph Weiler, for instance, distinguishes formal and social legitimacy, where formal legitimacy is 'akin to the juridical concept of formal validity'. ${ }^{28}$ This paper distinguishes between legal, moral and social legitimacy — these labels express the distinctions between the various concepts of legitimacy well and are in reasonably common use in international law scholarship.

\section{A LEgAL LEgITIMACY}

The term 'legitimacy' is etymologically derived from the Latin legitimus (lawful), as derived from lex (law), so it is not surprising that lawyers stake a claim to the word. Legal legitimacy is generally treated as the narrowest of the three disciplinary concepts of legitimacy. It may thus be defined as a property of an action, rule, actor, or system which signifies a legal obligation to submit to or support that action, rule, actor or system. Legal legitimacy is similar to moral legitimacy in that both assess given objects against particular normative framework; as such they are both sometimes grouped together as forms of 'normative legitimacy'. ${ }^{29}$ To writers outside of legal scholarship, legal legitimacy is often directly equated with legal validity, to the exclusion of questions of moral justifiability..$^{30}$ Legal validity in itself is then treated as a relatively straightforward concept. ${ }^{31}$ It is nonetheless recognised that legal legitimacy is particularly important because of the strength of its self-justification in a functioning legal system; once something has become legally legitimate, this provides an exclusionary reason for compliance even in the face of opposing moral considerations. ${ }^{32}$ Questions of legal validity thus have a direct impact on broader understandings of morality and order.

23 See Chris Thornhill and Samantha Ashenden (eds), Legality and Legitimacy: Normative and Sociological Approaches (2010); Allen Buchanan and Robert O Keohane, 'The Legitimacy of Global Governance Institutions' in Rüdiger Wolfrum and Volker Röben, Legitimacy in International Law (2008) 25, 25.

24 Achim Hurrelmann, Steffen Schneider and Jens Steffek (eds), Legitimacy in an Age of Global Politics (2007); Fritz W Scharpf, 'Reflections on Multilevel Legitimacy' (2007) Max Planck Institute for the Study of Societies Working Paper 07/03, available at <http://www.mpi-fgkoeln.mpg.de/pu/workpap/wp07-3.pdf>.

${ }^{25}$ Lars Vinx, Hans Kelsen's Pure Theory of Law: Legality and Legitimacy (2007) 60. See also Joseph Raz's distinction between de jure and de facto authority: Joseph Raz, The Authority of Law (2nd ed, 2009) 5.

26 Applbaum, above n 17, 76.

${ }^{27}$ David Beetham distinguishes between legal validity (legitimacy for lawyers), moral justifiability (legitimacy for philosophers), and belief in legitimacy (legitimacy for social scientists): David Beetham, The Legitimation of Power (1991) 4-7. Fallon also identifies legal, moral and sociological legitimacy: Fallon, above n 3, 1794-1801.

28 JHH Weiler, The Constitution of Europe (1999) 80.

29 Although the term 'normative legitimacy' is also sometimes deployed to mean solely moral legitimacy: see Applbaum, above n 17, 76-80.

30 See, e.g., Beetham, above n 27, 4 (emphasis in original).

31 See, e.g., ibid, 4-5.

32 See Joseph Raz, Practical Reason and Norms (1975) 39-48. Finnis describes 'exclusionary reasons' as 'a reason for judging or acting in the absence of understood reasons, or for disregarding at least some 
That non-lawyers commonly conflate the concepts of legal legitimacy and validity is understandable, as this is a move commonly undertaken by lawyers themselves. ${ }^{33}$ For lawyers, however, the question of legal validity is anything but straightforward. This is particularly so when it comes to international law, where the very possibility of legal validity still must fight to be acknowledged. Here, therefore, is an area where lawyers can meaningfully contribute to legitimacy debates on account of their specific expertise.

The requirements for legal validity have been the subject of longstanding debate; the following is only a brief sketch of the most prominent approaches. There are generally thought to be two main schools of thought as to the requirements for legal validity, in the forms of positivism and natural law theory. ${ }^{34}$ In the positivist tradition, represented most famously by Hans Kelsen and HLA Hart, to claim that a law is legally valid is to claim that it was created in accordance with the correct legal process. In Kelsen's view, this test for positive validity could be conducted recursively until a non-legal fundamental norm for a legal system, the grundnorm, could be reached, for which authority is 'presupposed'. ${ }^{35}$ Kelsen even articulated a 'principle of legitimacy', which referred to the persistence of a norm's legal validity until its replacement or repeal in accordance with the legal order that produced it. ${ }^{36}$ For Hart, legal validity was ultimately traceable to a 'rule

reasons which are understood and relevant and would in the absence of the exclusionary reason have sufficed to justify proceeding in some other way': John Finnis, Natural Law and Natural Rights (1980) 233.

33 See, e.g., in international law scholarship: 'Legal legitimacy takes what might be called an internal perspective: particular directives are justified in terms of a regime's secondary rules about who can exercise authority, according to what procedures, and subject to what restrictions': Daniel Bodansky, 'The Legitimacy of International Governance: A Coming Challenge for International Environmental Law' (1999) 93 American Journal of International Law 596, 608;'legal legitimacy being understood as the obligation to keep strictly within the frame of the original mandate. This refers to the option of inducing legitimacy through procedure': Rüdiger Wolfrum, 'Legitimacy of International Law from a Legal Perspective: Some Introductory Considerations' in Rüdiger Wolfrum and Volker Röben, Legitimacy in International Law (2008) 1, 23. See also, more ambiguously: 'The notion of formal legitimacy in institutions or systems implies that all requirements of the law are observed in the creation of the institution or system': Weiler, above n 28, 80. Cf Jean D'Aspremont, who carefully distinguishes between the issues of 'formal law-ascertainment' and 'why international law is binding or why subjects abide by its rules': Formalism and the Sources of International Law: A Theory of the Ascertainment of Legal Rules (2011) 22-3. The dictionary definitions of legitimacy tend to combine the moral and legal senses of the term. The Oxford English Dictionary, for example, defines legitimacy as: 'Of a government or the title of a sovereign: The condition of being in accordance with law or principle. Now often, with respect to a sovereign's title, in a narrower sense: The fact of being derived by regular descent; occas the principle of lineal succession to the throne, as a political doctrine'. Some writers adopt more idiosyncratic definitions of 'legal legitimacy' which do not correspond to legal validity. Brunnée and Toope, for instance, argue that legitimacy has a 'specific, legal meaning' tied to the satisfaction of specific criteria of legality: above n 7, 54. These may be understood, however, as representing particular conceptions of moral or social legitimacy that are strongly tied to legal criteria, and will be dealt with below.

34 There are almost as many variants of each theory as there are authors; it is beyond the scope of this paper to cover every such variant.

35 Hans Kelsen, General Theory of Law and State (Anders Wedberg trans, 2007) 110-22.

36 Ibid, 117-18. Kelsen qualifies the principle of legitimacy with the principle of effectiveness: 119 . See also Hans Kelsen, Principles of International Law (1952) 412-14. Cf Hersch Lauterpacht, 'General Rules of the Law of Peace' in E Lauterpacht (ed), International Law: Collected Papers (Volume 1: The General Works) (2009) 324. 
of recognition' - in contrast to Kelsen's grundnorm, the rule of recognition is a social fact rather than a norm. ${ }^{37}$ In basic terms, then, for a positivist, a norm is legally legitimate if it is created and persists in accordance with correct legal process, in which correctness is ultimately derived from a basic norm or from social consensus. Actions taken in accordance with such norms, and actors appointed to positions of authority in accordance with such norms, can also be said to possess legal legitimacy. In international law scholarship there is still much conceptual disagreement about what constitutes a correct legal process, particularly when it comes to determining the sources of international law. ${ }^{38}$

Central to the positivist view of legal validity is also the idea that legal validity and the moral justifiability of the law's substance are entirely separable. The formal fact of legal validity engenders a legal, but not necessarily a moral, obligation to obey. ${ }^{39}$ Hence no moral obligation necessarily arises either on the basis of the substance of law or due to its character as law. ${ }^{40}$ This is not to say that law cannot be moral or immoral, simply that the question of moral justifiability lies outside the question of legality. From this perspective, legal validity is a purely formal fact — an 'amoral datum'. ${ }^{41}$ The conflation between legitimacy and legal validity, when combined with this separation between legal validity and moral justifiability, raises some concerns. Analytically, distinguishing between legal validity and moral justifiability can be very important. However, taking legal validity to exhaust the concept of legitimacy has the potential to severely limit debates about international law. Questions of formal validity may crowd out broader questions about ethics and justice in international law matters — questions about which international lawyers should be very much concerned. ${ }^{42}$

The classical natural law tradition, in contrast, is often said to have treated substantive moral justifiability as an essential element of legal validity. Thomas Aquinas, for instance, is often quoted as stating that if in any point [human law] deflects from the law of nature, it is no longer a law but a perversion of law';43

\footnotetext{
${ }^{37}$ HLA Hart, The Concept of Law (2nd ed, 1994) 100-10.

38 See generally D'Aspremont, above n 33, ch 1.

39 Note that Kelsen's grundnorm may be read as providing the normative basis for the obligation to obey the law; however its role as the basis for law's normativity was never fully explored, and whether its obligatory character was legal or moral in nature was not fully addressed: see Andrei Marmor, 'The Pure Theory of Law' (7 July 2010) in Stanford Encyclopedia of Philosophy at $<$ http://plato.stanford.edu/entries/lawphil-theory/\#NorLaw>.

${ }^{40}$ Fallon distinguishes between the 'substantive legal legitimacy of judicial rulings', which relates to their correctness or plausibility as law, and 'their authoritative legitimacy or legally binding character': Fallon, above $n$ 3, 1794-5.

${ }^{41}$ Lon L Fuller, 'Positivism and Fidelity to Law: A Reply to Professor Hart' (1958) 71 Harvard Law Review 630, 656. Note however the that even the process of articulating the supposed functions of the law and stressing the importance of separating legal from moral discourse may be understood as normative projects: see Stephen Perry, 'Hart's Methodological Positivism' and Jeremy Waldron, 'Normative (or Ethical) Positivism', in Jules Coleman (ed), The Practice of Principle (2001) 311 and 410.

${ }^{42}$ See also Brunnée and Toope who refer to their 'interactional' account of legitimacy as enabling international lawyers to place debates about state consent, sources and the like 'in the broader context of the international legal enterprise, so as to better appreciate the roles they play, their potential, and their limitations': above n 7, 7-8.

43 Thomas Aquinas, Summa Theologica, I-II, Q.95, A-II.
} 
while William Blackstone wrote that 'no human laws are of any validity, if contrary to [the law of nature]'. ${ }^{44}$ Many legal philosophers, including Austin, ${ }^{45}$ Kelsen, ${ }^{46}$ Hart ${ }^{47}$ and $\mathrm{Raz},{ }^{48}$ have read these statements as indicating that, for natural lawyers, moral justifiability constitutes an inextricable aspect of legal validity. The quintessential distillation of natural law thinking — that 'unjust law is not law' has thus been interpreted as arguing that positive law is invalidated if morally disagreeable. Echoes of this idea may be found in contemporary approaches to jus cogens norms in international law, in that such norms are considered non-derogable and their basis is sometimes ascribed to natural law. ${ }^{49}$

Contemporary natural lawyers such as John Finnis, however, reject this reading as a mere caricature invented by the positivists..$^{50}$ Finnis argues that there are two different meanings of 'law' at play in the statement 'an unjust law is not law'.51 The first 'law' refers to human-made, positive law, and will continue to exist as such in accordance with the principles of positive legal validity and enforcement in its system of origin. The second use of 'law' means law which has full moral obligatory force, as all law should have. Although laws that lack moral legitimacy retain their status as law, they are defective in that they fail to achieve the quality of moral obligation that should be experienced in relation to law. Finnis thus separates out the question of law's validity from the question of its moral justifiability, and agrees that legal validity is a question of social fact. In this limited respect, Finnis finds common ground with the positivists..$^{52}$ In addition, Finnis argues explicitly that laws 'can and presumptively do (defeasibly) create moral obligations that did not as such exist prior to the positing of the rules'. ${ }^{53}$ This suggests that legal validity simultaneously gives rise to a species of moral legitimacy due to the inherent nature of the legal form, ${ }^{54}$ independently of the content of the law. This presumptive moral legitimacy may be defeated by a competing claim to the moral illegitimacy of a given law if that content is however materially unjust $\mathrm{t}^{5}$ or seriously immoral. 56

\footnotetext{
44 William Blackstone, Commentaries on the Laws of England, Volume 1 (1771) 41.

45 John Austin, The Province of Jurisprudence Determined (1853) Lecture V.

46 Hans Kelsen, 'The Natural Law Doctrine before the Tribunal of Science' (1949) II(4) Western Political Quarterly 481, 485.

47 Hart, above n 37, 208-12.

48 Joseph Raz, 'Kelsen's Theory of the Basic Norm' (1974) 19 American Journal of Jurisprudence 94, 100.

49 See Mary Ellen O'Connell, 'Jus Cogens: International Law's Higher Ethical Norms' in Donald Earl Childress III (ed), The Role of Ethics in International Law (2012) 78.

${ }^{50}$ Finnis, Natural Law and Natural Rights, above n 32, 25-9.

51 Ibid, 24.

52 ' $[\mathrm{n}$ relation to the settled positive law, natural law theory — as is acknowledged by a number of legal positivists $[\ldots]$ shares the principal thesis of contemporary legal positivists, that laws depend for their existence and validity on social facts.': John Finnis, 'Natural Law Theories' (5 February 2007) Stanford Encyclopedia of Philosophy <http://plato.stanford.edu/entries/natural-law-theories $>$.

53 Ibid.

${ }^{54}$ See also Lon L Fuller, The Morality of Law (revised ed, 1969).

55 Finnis, Natural Law and Natural Rights, above n 32, 27.

${ }^{56}$ Finnis, 'Natural Law Theories', above n 52.
} 
Even positive legal validity is not clear cut in many cases, as 'rules do not spell out the conditions of their application'. ${ }^{57}$ For a given legal problem there is often a range of permissible legal interpretations. The interpretation of particular laws frequently changes over time, and hence the question of whether a particular decision or norm is legally valid remains in flux. Furthermore, a given interpretation may accord more or less with a set of legal sources or with 'fundamental' legal principles that are meant to guide the development of the law. Consequently it is possible to speak of more or less legally legitimate actions, rules, institutions or systems depending on the emphasis one places on the determinative criteria for positive legal validity. Anthea Roberts, for instance, notes that legitimacy may be used to complicate the binary choice between valid or invalid law by providing a 'spectrum' where 'laws and actions may be more or less legitimate depending on the circumstances'.58

\section{B}

\section{Moral LegitimaCy}

Another common understanding of legitimacy is that of moral legitimacy. Moral legitimacy is often framed in terms of who has the "right to rule'59 - that is, how the exercise of power by one actor over another can be morally justified. Moral legitimacy consequently posits an 'ought' into the given power relationship. Moral legitimacy may thus be defined as a property of an action, rule, actor or system which signifies a moral obligation to submit to or support that action, rule, actor or system. Its opposite is moral illegitimacy. If something is morally illegitimate, then there is no moral obligation to submit; there may even be a moral obligation to resist. ${ }^{60}$ Moral legitimacy is thus closely bound up with questions of political authority.

There are endless potential configurations of moral legitimacy. ${ }^{61}$ Over the centuries many different conceptions of morally legitimate rule have been advanced. Plato suggested a system of quasi-celibate philosopher-king guardians as the appropriate rulers. ${ }^{62}$ Aristotle identified six modes of rule, the first three of which were considered justifiable (royalty, aristocracy and constitutional government), while the second three (tyranny, oligarchy and democracy) were considered perversions of the first three. ${ }^{63}$ Egyptian pharaohs, French sun-kings

57 Koskenniemi, 'Miserable Comforters', above n 10, 413, paraphrasing Immanuel Kant, Critique of Pure Reason (1991) 140-1.

58 Anthea Roberts, 'Legality vs Legitimacy: Can Uses of Force be Illegal but Justified?' in Philip Alston and Euan MacDonald (eds), Human Rights, Intervention, and the Use of Force (2008) 179, 208-09.

59 See Allen Buchanan, 'The Legitimacy of International Law' in Samantha Besson and John Tasioulas (eds), The Philosopby of International Law (2010) 79, 79; John Tasioulas, 'The Legitimacy of International Law' in Samantha Besson and John Tasioulas (eds), The Philosophy of International Law (2010) 97, 97; Coicaud phrases this as 'the right to govern': Jean-Marc Coicaud, Legitimacy and Politics: A Contribution to the Study of Political Right and Political Responsibility (David Ames Curtis trans, 2002) 10.

60 See David A Strauss, 'Reply: Legitimacy and Obedience' (2005) 118 Harvard Law Review 1854.

61 The possibility of multiple conflicting versions of moral legitimacy accounts for how rules, actors and systems that are considered legitimate in one framework may be criticised from another.

62 See generally Plato, The Republic and Other Works (Benjamin Jowett trans, 1980).

63 Aristotle, Politics (Benjamin Jowett trans, 1885) Book III, chapter VII. 
and contemporary North Korean despots have all claimed a right to rule deriving from the divine. ${ }^{64}$ Since the $17^{\text {th }}$ century the debate in liberal democratic states has focused on the tension between individual freedom and state power, somehow mediated by consent in the form of the social contract. ${ }^{65}$ Contemporary writings on moral legitimacy are dominated by notions of democratic legitimacy, with subgenres concerned with individual consent, the social contract and deliberation. This tendency is so widespread that often the term 'legitimacy' is used as shorthand for 'democratic legitimacy'. ${ }^{66}$ The preponderance of such writings has operated to eclipse the study of other forms of moral legitimacy.

Some writers have expressed concern at the apparent semantic redundancy of the moral sense of legitimacy. ${ }^{67}$ Surely it is simpler and clearer to refer to the specific moral basis for rule rather than to couch it in terms of legitimacy? Why focus on a government's legitimacy when you can jump straight to whether a government is sufficiently democratic, or insufficiently just? Such concern ignores the distinction between particular conceptions of legitimacy and the overarching concept of legitimacy. Moral legitimacy, as a concept, is primarily useful as a metaconcept, a way of referring to and comparing different conceptions of moral legitimacy. It enables questions of the form: 'Is a government more legitimate if it follows democratic processes or if it produces just outcomes?' and 'Are all forms of democracy equally legitimate?'. It allows for discussions of relative legitimacy in a way that is closed off by the self-contained languages of particular conceptions of moral legitimacy. It thus also highlights just how historically contingent current understandings of moral legitimacy may be, and opens up space for imagining and adopting alternative visions of legitimacy. At the same time, the use of 'legitimacy' highlights the common concerns of the different conceptions of legitimacy as regards authority, order, stability, obligation, obedience ${ }^{68}$ and power.

Each of the various forms of moral legitimacy articulated over the last several centuries has had its fair share of lawyers, politicians and philosophers ready to act as apologists or critics, contributing to increasingly elaborate justificatory apparatus for various modes of rule. ${ }^{69}$ This intermingling of power with attempts

${ }^{64}$ For examples of claims to divine ordination from Japan to England, see Reinhard Bendix, Kings or People: Power and the Mandate to Rule (1978).

65 See Flathman, above n 2, 679; Thomas Hobbes, Leviathan (1651); Jean-Jacques Rousseau, Du contrat social (1762); John Locke, The Second Treatise of Government (1689).

66 See, e.g., Elsig, above n 9.

67 See, e.g., James O'Connor, 'The Meaning of "Legitimacy" in World Affairs: Does Law + Ethics + Politics = A Just Pragmatism or Mere Politics?' (presented at Standing Group on International Relations Conference, Turin, 13 September 2007) available at <http://turin.sgir.eu/uploads/oconnorlegitimacy.pdf> 10-11.

68 See David A Strauss, 'Reply: Legitimacy and Obedience' (2005) 118 Harvard Law Review 1854.

${ }^{69}$ Beetham identifies three ways that legitimacy has been used in the political philosophical tradition: as a mode of apology for existing power structures; as criticism of those structures; and as a vocabulary for setting out the conditions of valid/morally justifiable power: Beetham, above n 27, 5. Fallon further divides this third category between ideal conditions and minimal conditions of moral legitimacy. Ideal conditions are those which rulers must aspire to and which, if somehow achieved, would ensure their 
to define the conditions of legitimate rule has ensured that not only have the various conceptions of legitimacy played a powerful role in shoring up or destabilising rule, but also that these conceptions have been informed and shaped by the realities of power.

The moral version of legitimacy remains intimately connected to the study of law, and to the question of legal authority. ${ }^{70}$ In contemporary societies, law is the preeminent means for the exercise of systemic power. International law embodies, normalises and enforces particular conceptions of the world. It informs our understandings of what is moral even as it is shaped by such understandings. Moral legitimacy is therefore central to the description and evaluation of the exercise of power through law. It is highly relevant to lawyers engaged in institutional design, in disputes steeped in moral issues, and for an appreciation of what it means to commit to a particular set of legal structures. Lawyers engaged in such projects may have a technical legal role to fulfil, but that role is only enhanced by an appreciation of the moral legitimacy concerns associated with such projects.

Moral legitimacy has tended to feature in international law discourse in one of four ways. First, it has featured heavily in debates on the moral basis of obligation in international law - that is, debates about why international law is worthy of compliance in general terms. ${ }^{71}$ Traditionally a range of possible bases have been suggested, ranging from consent, to human dignity, to the realisation of common purposes. These debates, long dormant, have been revived in recent scholarship. ${ }^{72}$ Second, specific conceptions of moral legitimacy have provided a framework against which to evaluate international law. ${ }^{73}$ Such evaluation may highlight areas where legal reform is needed. ${ }^{74}$ From there, international law may be used as an instrument to promote or implement a particular vision of moral legitimacy - as evident in the recent attempts to 'democratise' international institutions. Third, conceptions of moral legitimacy may provide international law with competing,

rule was 'maximally justified'. Minimal conditions set out a threshold level of moral justifiability which must be met for a regime to deserve support: Fallon, above n 3, 1797-8.

70 Indeed, Bhikhu Parekh has criticised much of the 'post-Hobbesian' discourse on political obligation as overly concerned with reasons for why citizens should obey the law, to the neglect of broader conceptions of political obligation that might consider the relationship between citizens, community and political life: Bhikhu Parekh, 'A Misconceived Discourse on Political Obligation' (1993) XLI Political Studies 236.

${ }^{71}$ See especially James Leslie Brierly, 'The Basis of Obligation in International Law' in Hersch Lauterpacht and CHM Waldock (eds), The Basis of Obligation in International Law and Other Papers (1958) 1; Oscar Schachter, 'Towards a Theory of International Obligation' (1968) 8 Virginia Journal of International Law 300.

72 See, e.g., Matthew Lister, 'The Legitimating Role of Consent in International Law' (2010) 11(2) Chicago Journal of International Law 663.

73 Obiora Chinedu Okafor suggests that engaging in such evaluation is a professional imperative for international lawyers: 'International lawyers must transcend mere doctrinal analysis; to climb on its shoulders in the search for justice. It is therefore a valuable enterprise to examine ways of enhancing the normative legitimacy of international norm/rule producing institutions': 'The Global Process of Legitimation and the Legitimacy of Global Governance' (1997) 14(1) Arizona Journal of International and Comparative Law 117, 129.

74 See Roberts, above n 58, 209. 
rather than complementary, normative justifications for action. ${ }^{75}$ It is this third relationship that tends to pose the greatest concern to international lawyers worried about the dilution of international law's normative force.

\section{SOCIAL LEgITIMACY}

The third common understanding of legitimacy is social legitimacy. Social legitimacy may be defined as the property projected onto an action, rule, actor or system by an actor's belief that that action, rule, actor or system is morally or legally legitimate. ${ }^{76}$ Unlike legal or moral legitimacy, social legitimacy does not make a normative commitment to any relationship of power; it drops any sense of an objective 'ought'. It treats legitimacy as a social fact, not a normative goal. Nonetheless this definition does not completely disregard the role of moral and legal legitimacy. Social legitimacy is an empty concept without an account of the moral or legal framework to which the posited believer subscribes. Social legitimacy is an empirical concept, but it is one which is concerned specifically with what forms of power people believe to be morally or legally justified, even if those beliefs bear little relationship to the realities of power. It may be possible for authorities to maintain their social legitimacy despite frequently violating the normative justifications for their legitimacy. Social legitimacy thus allows for the concept of 'false legitimacy', where there is an internal disconnect between people's beliefs about the moral operation of a system and the actual operation of that system. ${ }^{77}$ This also helps to account for legitimacy's capacity to motivate obedience even for those who are consistently disadvantaged by the system. ${ }^{78}$

The widely recognised progenitor of the social approach is Max Weber. ${ }^{79}$ Weber saw human beings as inevitably involved in relationships of rule, where one person exerts rule/dominance/authority over others. He used the concept of legitimacy as an aid to understanding how such relationships are perpetuated or dissolved, based on the beliefs which justify the acceptance of rule. Legitimacy was viewed as a cause for such belief which could be distinguished from coercion, or mere self-interest. It was therefore a social motivation for obedience that could operate independently of either of these — an explanatory framework for

\footnotetext{
75 Ibid, 208.

76 Cf Ian Hurd, After Anarchy: Legitimacy and Power in the United Nations Security Council (2007) 7: 'Legitimacy refers the belief by an actor that a rule or institution ought to be obeyed'.

77 See Claire R Kelly, 'Institutional Alliances and Derivative Legitimacy' (2008) 29 Michigan Journal of International Law 605, 646-7. There is also a clear connection between the idea of 'false legitimacy' and legitimation in the ideological sense. See generally James D Fry, 'Legitimacy Push: Towards a Gramscian Approach to International Law' (2008) 13 UCLA Journal of International Law and Foreign Affairs 307.

78 Robin Stryker, 'Legitimacy' in International Encyclopedia of Social and Behavioural Sciences (2001) 8700, 8700 citing Richard L Dellafave, 'Toward an Explication of the Legitimation Process' (1986) 65 Social Forces 476; Fritz W Scharpf, Governing in Europe: Effective and Democratic? (1999).

79 Max Weber, Economy and Society: An Outline of Interpretive Sociology (1968) 31-8, 212-301.
} 
voluntary compliance towards rules ('maxims') because 'it is in some appreciable way regarded by the actor as in some way obligatory or exemplary'. .0

Social legitimacy, as with the other forms of legitimacy, is strongly tied to the analysis of legal structures. Weber's initial elaboration of legitimacy and the forms of 'pure' legitimate authority focused primarily on the exercise of legal authority, especially as operationalised through bureaucracy. ${ }^{81}$ He placed legitimacy firmly within a historical narrative in which modernity is characterised by the displacement of 'traditional' and 'charismatic' authority by instrumental 'legalrational' legitimacy in its many forms. ${ }^{82}$ Indeed, he argued that ' $[t]$ oday the most common form of legitimacy is the belief in legality, the compliance with enactments which are formally correct and which have been made in the accustomed manner'. ${ }^{83}$ Even removing the focus from specifically 'legal' ideal types of legitimacy, social legitimacy can prove useful for evaluating whether law's formal claims accord with the normative expectations of its subjects (and other interested parties). This has important implications for enforceability and compliance, as the greater the distance between legal or moral legitimacy and social legitimacy, the less stable and effective a legal system will be.

The wave of legitimacy scholarship in international law has largely focused on social legitimacy. Franck, for instance, identified his 'working definition' of legitimacy as 'a property of a rule or rule-making institution which itself exerts a pull toward compliance on those addressed normatively because those addressed believe that the rule of institution has come into being and operates in accordance with generally accepted principles of right process'. ${ }^{84}$ The emphasis here is on the beliefs of 'those addressed' and their capacity to facilitate compliance with international law, although it is worth emphasising that Franck never lost sight of the moral component of social legitimacy..$^{85}$ A similar emphasis on the relationship between social legitimacy and compliance with international law may be found in

\footnotetext{
${ }^{80}$ Ibid, 31.

81 Weber described the form of legitimate domination based on 'legal authority' as 'resting on a belief in the legality of enacted rules and the right of those elevated to authority under such rules to issue commands': Weber, Economy and Society, above n 79, 215. This form of social legitimacy, for Weber, was intended not to rely on beliefs in moral legitimacy, but on beliefs in a distinctly legal legitimacy characterised by rationality: Dyzenhaus describes Weber's approach as stating that the legitimacy accorded to legal authority 'would not arise out of any moral content inherent in legal order, but out of the particular kind of rationality inherent in legal order': David Dyzenhaus, Legality and Legitimacy: Carl Schmitt, Hans Kelsen and Hermann Heller in Weimar (1999) 237.

82 Weber, Economy and Society, above n 79, chapter III.

${ }^{83} \mathrm{Ibid}, 37$.

${ }^{84}$ Franck, The Power of Legitimacy among Nations, above n 7, 24.

85 'When it is asserted that a rule or its application is legitimate, two things are implied: that it is a rule made or applied in accordance with right process, and therefore that it ought to promote voluntary compliance by those to whom it is addressed. It is deserving of validation.' Thomas M Franck, Fairness in International Law and Institutions (1995) 26 (emphasis added).
} 
the work of Harold Koh, 86 Antonia and Abram Chayes, ${ }^{87}$ and Jutta Brunnée and Stephen Toope. ${ }^{88}$

The direct association between compliance and legitimacy can become problematic, however, when compliance is taken as the end in itself and the underlying reasons for compliance are ignored. This undermines opportunities for critical reflection on the values and purposes of international law and dispenses with the possibility of articulating alternative approaches to global problems. Compliance should never be taken as an independent normative goal in itself - it is only a tool for the achievement of other goals. ${ }^{89}$ Koskenniemi cites a note of caution about focusing on compliance in this way, as it results in a 'managerial position that no longer questions the need for "compliance" and is only concerned over the "legitimacy" of institutions to which everyone is assumed to have already committed'. 90 The concept of social legitimacy does not in itself, however, necessitate such a limited view. Social legitimacy relates to beliefs about normative legitimacy. As such, debates about legitimacy should point not only to how compliance may be maximised, but also to more fundamental questions about why laws and institutions are worthy of compliance at all. Moreover, as discussed further below, there may be alternative motives for compliance other than legitimacy, including coercion, self-interest and habit.

\section{LEGITIMATION}

The disconnect between people's beliefs about whether or not power is normatively (that is, legally or morally) legitimate, and whether or not it may be considered normatively legitimate in any objective sense (within a given framework), leads to the concept of legitimation. Legitimation is the process by which actors come to believe in the normative legitimacy of an object. ${ }^{91}$ Legitimation may occur as the result of a conscious effort to influence beliefs about what is normatively justified, or as the product of the unconscious

${ }^{86}$ Harold Hongju Koh, 'Why Do Nations Obey International Law?' (1997) 106 Yale Law Journal 2599.

${ }^{87}$ Abram Chayes and Antonia Handler Chayes, The New Sovereignty: Compliance with International Regulatory Agreements (1998).

88 Above $\mathrm{n} 7$.

${ }^{89}$ For an example of a focus on compliance to the exclusion of legitimacy, see Eric A Posner and John C Yoo, 'A Theory of International Adjudication', University of Chicago John M Olin Law and Economics Working Paper No 206; UC Berkeley Public Law Research Paper No 146 (2004); cf Laurence R Helfer \& Anne-Marie Slaughter, 'Why States Create International Tribunals: A Response to Professors Posner and Yoo' (2005) 93 California Law Review 1.

${ }^{90}$ Koskenniemi, 'The Mystery of Legal Obligation' (2011) 3(2) International Theory 319, 320.

${ }^{91}$ Cf legitimation as 'the process by which authority comes to seem valid and appropriate': Susan Marks, The Riddle of All Constitutions (2000) 19. Drawing on Marxist thought, Marks provides a highly useful breakdown of 'characteristic legitimation strategies', including rationalisation, normalisation, narrativisation, dissimulation, inversion, displacement, unification, universalisation, simplification, reification, and naturalisation: 19-22. This collection of strategies provides something of a tool box that can be used to analyse how discursive mechanisms may be used strategically, or even inadvertently, to construct various notions of what is legitimate. 
replication of pervasive legitimacy narratives. ${ }^{92}$ Whereas each form of legitimacy represents a property, legitimation represents action. It may either be narrowly strategic, ${ }^{93}$ or part of a process of public discourse leading to more broadly legitimate outcomes. ${ }^{94}$

Legitimation processes are not limited to mere assertions of legitimacy. They involve the articulation and practice of a highly complex and developed set of interconnected symbols and rituals, often pointing to underlying moral criteria. Peter Berger and Thomas Luckmann, for instance, define legitimation as 'a process of explaining and justifying the validity of an institutional order'. They identify four successive levels of legitimation:

1) the 'linguistic objectification of human experience', through creating a vocabulary through which legitimation may be transmitted;

2) the articulation of a set of 'rudimentary' moral propositions;

3) the creation of 'explicit theories' to legitimate different institutional sectors; 95 and

4) the development of a 'symbolic universe' that 'integrate[s] different provinces of meaning and encompass[es] the institutional order in a symbolic totality'. ${ }^{96}$

The creation, interpretation and enforcement of law combine to form a quintessentia 197 legitimation process. Effective laws have the power to create legal and moral obligations where none existed previously, regardless of substance. These obligations exist not only in the abstract 'out there', but are internalised by various actors in the legal system. ${ }^{98}$ Even Kelsen, refuting TH Huxley, argued that:

92 'Ideology almost invariably operates in this mode, and the various other modes of operation of ideology which I shall discuss can be thus understood in most cases as specific forms of legitimation': ibid, 19.

93 Those with an interest in maintaining the social order tend to see legitimation as a good, and make conscious attempts at legitimation: see Rodney S Barker, Legitimating Identities: The Self-Presentations of Rulers and Subjects (2001). Critical voices have regularly positions themselves against legitimation as producing either false consciousness, subliminal technologies of the self, or domination.

94 See Omid A Payrow Shabani, Democracy, Power and Legitimacy: The Critical Theory of Jürgen Habermas (2003) chapter 4; Jens Steffek, 'The Power of Rational Discourse and the Legitimacy of International Governance' (EUI Working Paper, RSC No 2000/46) 14-17; the question of what constitutes the 'public' in this context for the international sphere has yet to be fully explored.

95 Parallels may be seen here with Peter Haas's 'epistemic communities' and Koskenniemi's 'functional differentiation': Peter M Haas, 'Introduction: Epistemic Communities and International Policy Coordination (1992) 46 International Organization 1; Martti Koskenniemi, 'The Fate of Public International Law: Between Technique and Politics' (2007) 70(1) Modern Law Review 1.

96 Peter L Berger and Thomas Luckmann, The Social Construction of Reality (1966) 112-13.

97 Weber's writings on legitimacy expressly recognised the 'potential centrality of legal order for the legitimacy, and hence stability, of the broader political system', Stryker, above n Error! Bookmark not defined., 8700-01. Several other authors have pointed to law as the legitimating structure par excellence.

98 See Harold Hongju Koh, 'Transnational Legal Process' (1994) 75 Nebraska Law Review 181; Brunnée and Toope, above n 7; Ryan Goodman and Derek Jinks, 'How to Influence States: Socialization and International Human Rights Law’ (2004) 54 Duke Law Journal 621. 
[i] $\mathrm{f}$ the legal norm, enacted by the legislator, provides sanctions, and if such a "law" becomes the content of a man's consciousness, it can very well become a motive of his behaviour and hence a cause of his paying his taxes or his abstaining from theft and murder. A legislator enacts norms only because he believes that these norms, as motives in the mind of men, are capable of inducing the latter to the behaviour desired by the legislator. ${ }^{99}$

The process of legitimation is not directly related to the degree of legitimacy enjoyed by its target. Organisations which have previously enjoyed legitimacy and have a highly sophisticated legitimation apparatus, with the most complex symbolic universes formed in human history, may still find their legitimacy eroding. The decline of the Holy Roman Empire provides one of the more obvious examples. Similarly, actions and ideas previously considered wholly illegitimate may be subjected to the full brunt of legitimating strategies: the US's attempts to justify the invasion of Iraq in 2003 on the basis of pre-emptive selfdefence and the 'new threat' posed by modern terrorism provide a contemporary example. Awareness of this dynamic nature of legitimation is crucial to avoid the trap of too easily conceding legitimacy to established rules, institutions and practices.

\section{E MIXED APPROACHES}

The three categories of legal, moral and social legitimacy are often treated as selfcontained. Yet each concept of legitimacy may affect how the others are understood. For instance, as social legitimacy is by definition founded on beliefs about moral and legal legitimacy, it can be seriously undermined by the discovery that such beliefs are unfounded, or the underlying beliefs change. In the other direction, Harold Koh has drawn attention to how enmeshing international lawyers and other international actors in a web of procedural obligations and practices of legal decision-making can inspire a social-psychological 'buy-in' to the underlying procedural framework. This suggests that feelings of social legitimacy can help to influence underlying ideas about moral legitimacy. ${ }^{100}$

Dissatisfaction with purely normative or social conceptualisations of legitimacy has led various authors to straddle the moral/social divide, by incorporating a social element when articulating the moral criteria for legitimacy. Jürgen Habermas is a leading figure in this tradition. Habermas's approach to legitimacy is idiosyncratic and complex. For Habermas, '[1]egitimacy means there are good arguments for a political order's claim to be recognized as right and just:

\footnotetext{
${ }^{99}$ Kelsen, General Theory of Law and State, above n 35, 166.

100 See, e.g., Harold Hongju Koh, 'The Value of Process' (2005) 11 International Legal Theory 27, 28: 'Most compliance comes from obedience. Most obedience comes from norm internalization. Most norm internalization comes from process'.
} 
a legitimate order deserves recognition. Legitimacy means a political order's worthiness to be recognized. ${ }^{101}$ On first glance this would appear to be a standard moral legitimacy argument. However, what constitutes a 'good' argument in Habermas's approach is determined according to a process of communicative action/public deliberation. Whether or not something is legitimate is thus a 'contestable validity claim'. ${ }^{102}$ This therefore moves beyond a purely social account, yet avoids crossing the line entirely into moral legitimacy as it remains dependent on how a political order is perceived. ${ }^{103}$

David Beetham combines legal, moral and social approaches, requiring legal validity, shared beliefs and expressed consent as minimum conditions of legitimacy. He raises two objections to the Weberian approach. Firstly, a 'given power relationship is not legitimate because people believe in its legitimacy, but because it can be justified in terms of their beliefs'. ${ }^{104}$ This criticism transforms the idea of social legitimacy into a form of moral legitimacy, by characterising as 'legitimate' any order that satisfies the demands of moral legitimacy generated by its subjects. Although useful in highlighting the analytical role of moral legitimacy in evaluating whether social legitimacy is normatively well-founded, it goes too far in abandoning the possibility of a purely empirical form of legitimacy altogether. It also closes off the possibility of analysing processes of legitimation that are based on the consolidation of power rather than the perfection of right rule. As such, Beetham and Weber are essentially addressing different questions. Secondly, Beetham argues that a definition based primarily on belief ignores the capacity of other elements to confer legitimacy: such as through consent, or judicial determination. ${ }^{105}$ Yet a key aspect of social legitimacy is that it is not conferred in any absolute sense, but rather that ideas of what is morally legitimate are internalised by given subjects. Beliefs need not be static, and may change in response to external normative forces. Consent and judicial determination may become part of such internalised beliefs as to what constitutes morally legitimate forms of power by a given subject, at which point they could be accounted for by social legitimacy.

In international law scholarship, Jutta Brunnée and Stephen J Toope skilfully manage to incorporate elements of all three approaches: legal, moral and social. They argue that legitimacy has a 'specific, legal meaning'106 which goes beyond

\footnotetext{
101 Jürgen Habermas, Communication and the Evolution of Society (1979) 178. See also David Dyzenhaus, 'The Legitimacy of Legality' (1996) 46 University of Toronto Law Journal 129.

102 Habermas, Communication and the Evolution of Society, above n 101, 178.

103 Jens Steffek takes an explicitly Habermasian approach to legitimacy in international governance: Steffek, above n 94; Jens Steffek, "The Legitimation of International Governance: A Discourse Approach' (2003) 9(2) European Journal of International Relations 249. Steffek notes that Habermas's early writings on legitimacy were specifically set against Weber's conception, in an attempt to formulate a communicative action approach, rather than the strategic action he interpreted Weber as advocating: 14-15. See also Beetham's critique of Habermas, above n 27, 15.

${ }^{104}$ Beetham, above n 27, 11.

105 Ibid, 12.

106 See Brunnée and Toope, above n 7, 54.
} 
tests for validity. ${ }^{107}$ Drawing on the work of Lon Fuller, they develop an 'interactional account' of legitimacy in which adherence to eight criteria of legality (generality, promulgation, non-retroactivity, clarity, non-contradiction, not asking the impossible, constancy and congruence between rules and official action) 'produces a law that is legitimate in the eyes of the person to whom it is addressed'. ${ }^{108}$ Legitimacy is generated in a social sense through the creation of communities of practice in which adherence to the criteria of legality generates shared understandings about the law. These understandings carry with them a sense of moral obligation to comply with the law. Moreover, the fulfilment of these criteria is argued to have moral worth, in that it entails a 'commitment to autonomous actor choices and diversity' as well as to processes of communication. ${ }^{109}$

\section{THREE ELEMENTS OF LEGITIMACY}

Having established the major categories of legal, moral and social legitimacy, it is worth further breaking them down into their distinctive components. Each conception of legitimacy involves a different permutation of three elements: the legitimated object, the legitimating subject and the basis for legitimacy. This part discusses each of these three elements in turn.

\section{A OBJECTS OF LEgITIMACY}

Each of the categories provided above differentiate between when legitimacy is applied to actions, norms, actors and systems. ${ }^{110}$ As Ian Hurd and Katharina Coleman have highlighted, ${ }^{111}$ the legitimacy of each of these object types can be treated separately, even in the same factual context. Hence, the US invasion of Iraq (an action) could be criticised as morally illegitimate, even by those who still recognised the legitimacy of the US (an actor) as a state and major power, while the US criticised the legitimacy of existing restrictions (norms) on self-defence, while others criticised the Security Council (an institution) for being illegitimate

\footnotetext{
107 Ibid, 7.

108 Ibid, 27.

109 Ibid, 9 and 28-33.

110 See Katharina P Coleman, International Organisations and Peace Enforcement: The Politics of International Legitimacy (2007) 20-3. Similarly David P Rapkin and Dan Braaten suggest 'actors [...], ideas, ideologies, norms, rules, policies, or actions [...]': 'Conceptualising Hegemonic Legitimacy' (2009) 35 Review of International Studies 113. '[Legitimacy theory] now encompasses acts, persons, roles, and rules, hence the structure of relations and groups, and the groups themselves (particularly important to the legitimation of emerging nations': Zelditch, above n 18, 40

111 Hurd, above n 76; Coleman, above n 110, 23.
} 
because it failed to prevent the invasion, or the international legal order (a system) for proving so impotent.

The legal, economic, social and cultural links between various objects of legitimacy ensure that what affects one will often affect another. In the short term, however, even intimately connected objects tend to operate, for legitimacy purposes, independently. Hence the WTO's dispute settlement system may be said to enjoy widespread legitimacy even though panels may occasionally issue reports that are considered seriously deficient, and the UN Security Council may retain legitimacy even when it refuses to confront massive human rights violations in Syria. Depending on the object of legitimacy, different legitimating mechanisms may apply, and its legitimacy may be subjected to greater or lesser scrutiny. When engaging in legitimacy debates, it is thus important to be clear about exactly what one is arguing to be legitimate or illegitimate. ${ }^{112}$

The way that different views of legitimacy may be attached to different objects in the same context helps to account for the quicksilver nature of legitimacy assessments, and why they can be so readily manipulated. A specific decision which may have been considered controversial on its own terms may be justified on the basis that it was issued by a legitimate individual or institution, or because it claims to accord with a legitimate norm, or to have been produced according to a legitimate procedure, notwithstanding its substantive content or its practical effects. ${ }^{113}$ Legitimacy can therefore, often problematically, provide a discursive space for the displacement of responsibility fordecisions.

Determinations as to legitimacy, whether legal, moral or social, may transform the object to which they are applied. Inis L Claude, Jr writes that ' $\mathrm{t}]$ here is, of course, a correlation between the nature of the legitimizing principle and the identity of its applicator. For instance, the principle of divine right tends to call for an ecclesiastical spokesman, and the consent theory implies reliance on a democratic electoral process'.114 Yet the relationship goes further than this. Different conceptions of legitimacy not only call upon different types of authority figures to step into pre-assigned roles - they also constitute how those actors see themselves and how they are perceived by others. The roles transform their inhabitants. Hence the basis for an institution's legitimacy may bend the exercise of that institution's powers in particular ways, preferring certain interests while marginalising others, and may alter the way the exercise of such power is perceived by various audiences.

\footnotetext{
112 Samantha Besson notes that ' $[\mathrm{m}]$ ost accounts [of the authority of international law] focus on the subjects to whom authoritative laws apply and elude the question of whose authority it is. Those few accounts that discuss law-making institutions include among them states and IOs (and other nongovernmental actors), but without distinguishing between them and without dissociating their roles between different law-making processes': 'The Authority of International Law — Lifting the State Veil' (2009) 31 Sydney Law Review 343, 359.

113 See also Flathman, above n 2, 678.

114 Inis L Claude, Jr, 'Collective Legitimization as a Political Function of the United Nations' (1966) 20 International Organization 367, 370.
} 


\section{B SubJects OF LEgItimacy}

Both legal and moral legitimacy assume that there is a subject who should submit to or support the legitimate object. Subjects may vary depending on the particular conception of legitimacy employed. They may, for instance, be citizens of a state, people in a state's territory, or adherents of a particular religion. The subjects of international law have traditionally been considered states. More recently, Jeremy Waldron has argued that the world's billions of individuals should be considered the 'true' subjects of international law, in moral if not formal terms. ${ }^{115}$ The subjects of legitimacy may have a complicated relationship with the objects of legitimacy. Waldron, again, notes that the state is not just a subject of international law; it is additionally both a source and an official of international law'. 116

It is important to differentiate the subjects of legal or moral legitimacy from the legitimating community or audience associated with social legitimacy. As discussed above, social legitimacy is constructed from beliefs about legal or moral legitimacy. As such, social legitimacy is only meaningful to the extent that it relates to a given audience. Social legitimacy must be projected by someone: ' $t$ ] here must be some social group that judges the legitimacy of an actor or action based on the common standards acknowledged by this group'.117 The subject of legitimacy and the legitimating community are thus not necessarily co-extensive (although they may be in specific conceptions of legitimacy). Moreover, it is not enough that a given group consider an object to be legitimate or illegitimate; they must judge that it is legitimate according to the same 'common standards' (or at least a similar enough family of reasons to make the concept of community meaningful) to constitute a legitimating community. There can be many legitimating communities for the one object, with differing and overlapping common standards. Nevertheless, certain legitimating communities may be more powerful, or be given a more normatively privileged status, than others. In most democratic frames of reference, for instance, the supreme legitimating community is notionally the voting public.

The international sphere clearly lacks as stable and central a legitimating community as the voting public at the domestic level. Traditionally, the legitimating community, too, has been assumed to be the group of states. Although states may still form the basic formal unit for the purposes of creating and enforcing international law, they have come together in a multiplicity of

\footnotetext{
115 Jeremy Waldron, ‘Are Sovereigns Entitled to the Benefit of the International Rule of Law?' (2011) 22 European Journal of International Law 315, 325-7. See also Mark Weston Janis, 'Individuals as Subjects of International Law' (1984) 17 Cornell International Law Journal 61; Kate Parlett, The Individual in the International Legal System (2011).

116 Jeremy Waldron, 'The Rule of International Law' (2006) 30(1) Harvard Journal of Law \& Public Policy 15, 23 (emphasis in original).

117 Coleman, above n 110, 24. Steffek denotes these as the 'dispensers of legitimacy': Steffek, above n 94, 57.
} 
normatively fragmented regimes that lack clear hierarchical relationships with one another. Nor is there any centralised authority to adjudicate conflicts between these regimes. Ian Clark posits that the lack of a clear, appropriate legitimating community in the international arena is one of the reasons why it took so long to translate the concept of legitimacy to the international sphere. ${ }^{118}$ Similarly the lack of an appropriate legitimating community may make a nonsense of the attempt to graft traditional domestic democratic forms of legitimacy onto international governance. In the words of Joseph Weiler: 'The international system form of governance with government and without demos means there is no purchase, no handle whereby we can graft democracy as we understand it back from Statal settings on to the international arena'. ${ }^{119}$

Membership in a community of legitimation is important as it is the members who get to determine the boundaries of what is and is not morally legitimate for that community. The interests and preferences of the members of any given legitimating community are nonetheless likely to be fluid and changeable over time. Moreover, if a legitimating community's membership is too limited, or if circumstances bring other actors or ideas to the fore, the community's authority to determine the boundaries of legitimacy for a given object may weaken, or fall to others entirely. The less powerful a given legitimating community, the less influence its conception of legitimacy is likely to have on the overall mix.120

Changes in understandings of what constitutes the relevant legitimating community over time can hence have significant implications for how power is distributed.121 Consider the GATT and the WTO — for decades, interest in the workings of the international trading system was largely confined to a select group of trade insiders. Formally, the legitimating community comprised the Contracting Parties (for the GATT) and the Members (for the WTO). Functionally, the legitimating community was made up of the agents of the Contracting Parties/Members and the 'insiders' who had access to such agents: trade officials, diplomats, lobbyists, academics. Robert Howse notes how this allowed for the exercise of power in the multilateral trading order to be legitimated on technocratic grounds. ${ }^{122}$ Yet as Robert Keohane and Joseph Nye note, this 'club model' was soon to fracture. ${ }^{123}$ As the international trading system pushed further into areas (such as public health and the environment) that were previously

\footnotetext{
118 Ian Clark, Legitimacy in International Society (2005) 11.

119 Joseph HH Weiler, 'The Geology of International Law - Governance, Democracy and Legitimacy' (2004) 64 Zä̈RV 547, 560.

120 Some have take this to the extreme: Henry Kissinger, for instance, claimed that the only relevant legitimating community in the international sphere is composed of the major powers: 'An international order, the basic arrangements of which are accepted by all the major Powers, may be called "legitimate["]': 'Reflections on American Diplomacy' (1956) 35(1) Foreign Affairs 37, 43; see also Kissinger, American Foreign Policy (1977) 145.

${ }^{121}$ See esp Ian Clark, International Legitimacy and World Society (2007).

122 Robert Howse, 'From Politics to Technocracy — And Back Again: The Fate of the Multilateral Trading Regime' (2002) 96 American Journal of International Law 94;

123 See Robert Keohane and Joseph F Nye, Jr, 'Between Centralization and Fragmentation: The Club Model of Multilateral Cooperation and Problems of Democratic Legitimacy' (2001) KSG Working Paper No 01-004, available at $<$ ssrn.com/abstract $=262175>$.
} 
considered the exclusive domain of domestic regulators, the system drew the attention of outsiders who were not satisfied by the technocratic model. The formal legitimating community remains the W'TO Members, but in substance there are now several legitimating communities competing to take the WTO in radically different directions: the trade policy insiders now vie with human rights activists, officials from developing countries, other intergovernmental organisations, anti-globalisation protestors and environmental lobby groups, among others. ${ }^{124}$ The trade policy insiders are still the ones with the most privileged positions when shaping the exercise of W'TO power. But they can no longer afford to ignore the very different ideas of legitimacy that are pushed by alternative legitimating communities. The proliferation of these legitimating communities requires a careful rethinking of the grounds for the WTO's moral legitimacy to accommodate its new realities. ${ }^{125}$

\section{The Bases of Legitimacy: Procedure, Substance, Outcome}

The third element is the basis for legitimacy; that is, the grounds on which an object is determined to be legitimate. These bases may be used to distinguish between procedural (or process-based), substantive and outcome-based forms of legitimacy. ${ }^{126}$ Procedural legitimacy is concerned with the mechanisms by which power is conferred and exercised.127 It prioritises the formal validity of power, focusing on secondary rules about the making, changing and destruction of laws, and the appointment and removal of officials. In Thomas Franck's words: 'A process, in this sense, is usually set out in a superior framework of reference, rules about how laws are made, how governors are chosen and how public participation is achieved'.128 Weber's articulation of social legitimacy was famously processbased, as it focused on types of legitimacy that arise by reference to particular sources, rather than to the substance of the rules or actions generated by those

\footnotetext{
124 See also Rapkin and Braaten, above n 110, 117-20.

125 In practice, this has resulted in an extensive literature on democratic legitimacy and the WTO: see, e.g., Robert F Housman, 'Democratizing International Trade Decision-Making' (1994) 27 Cornell International Law Journal 699; Steve Charnovitz, 'WTO Cosmopolitics' (2002) 24 International Law and Politics 299; Robert Howse, 'How to Begin to Think about the Democratic Deficit at the WTO' in Stefan Griller (ed), International Economic Governance and Non-Economic Concerns (2003) 79; Americo Beviglia Zampetti, 'Democratic Legitimacy in the World Trade Organization: The Justice Dimension' (2003) 37 Journal of World Trade 107; Elsig, above n 9; Steve Charnovitz, 'The WTO and Cosmopolitics' (2004) 7(3) Journal of International Economic Law 675.

126 Franck, The Power of Legitimacy among Nations, above n 7, 17-18 (process-based, procedural-substantive, and outcome-based); Ian Hurd, above n 76, 66-73 (process-based, fairness-based, and outcome based); Wolfrum, above n 33, 6 (citations omitted) (source-based, procedural, result-oriented); Clark, Legitimacy in International Society, above n 118, 18-19 (procedural and substantive).

127 Lawrence Friedman asserts that only procedural, input-based legitimacy is relevant to determining the legitimacy of a legal institution or system: Lawrence M Friedman, Law and Society - An Introduction (1977) 139.

${ }^{128}$ Franck, The Power of Legitimacy among Nations, above n 7, 17.
} 
sources. Franck also adopted a largely procedural approach to rule legitimacy with his criteria of coherence, consistency, adherence and symbolic validation. ${ }^{129}$

Procedural legitimacy is closely tied to the source of commands, rules and actions, as performed by various actors through given rituals. In the international sphere, both international law and the multitude of diplomatic practices represent different process-based forms of legitimation. The most commonly articulated archetypes of procedural legitimacy in the domestic realm (and in Europe) are the various forms of democratic legitimacy, ${ }^{130}$ while in international law they are those of consent. ${ }^{131}$ The procedural approach to legitimacy helps to explain why actors are willing to support particular power relationships over others even when they fail to serve their substantive interests in specific instances. Legal legitimacy, at least as conceived by the positivists, represents a particularly prominent form of process-based legitimacy. Law is the ultimate vessel for procedural legitimacy, as it claims an obligation to comply notwithstanding its substance. That said, the relevant processes need not be legal in nature. The prophecies of ancient Greek oracles, for instance, were accorded a form of process-based legitimacy following the satisfaction of a complex set of preparatory rituals.

The procedural approach may be concerned narrowly with the 'correctness' of procedure as measured against procedural rules, ${ }^{132}$ which may in turn be understood as reflecting a given substantive aim (e.g. democratic representation, or the rule of law). ${ }^{133}$ It stops short, however, of interrogating the desirability of a given substantive aim. Once a system or institution is constructed, its background norms are often taken for granted and its procedures are followed for their own sake without deeper consideration of whether they are serving a more fundamental substantive aim or resulting in the best outcomes.

\footnotetext{
${ }^{129}$ Ibid.

${ }_{130}$ See Victor Bekkers et al (eds), Governance and the Democratic Deficit: Assessing the Democratic Legitimacy of Governance Practices (2007); Scharpf, Governing in Europe, above n Error! Bookmark not defined.; Frederick M Barnard, Democratic Legitimacy: Plural Values and Political Power (2001). The procedural conception of democratic legitimation should not be confused with the aims of democracy itself: important though the institutions and procedures of representative government clearly are, they cannot be allowed to exhaust the meaning of democracy. To permit that is to give up on the idea that democracy is about self-government, and not just about legitimating government by others': Marks, above $\mathrm{n} 91,2$.

131 See James Leslie Brierly, 'The Basis of Obligation in International Law' in Hersch Lauterpacht and Claud HM Waldock (eds), The Basis of Obligation in International Law and Other Papers (1958) 1. That said, narrative of democratic legitimacy have also become quite prominent in international law scholarship: see, e.g., Markus Krajewski, 'Democratic Legitimacy and Constitutional Perspectives of WTO Law' (2001) 35(1) Journal of World Trade 167; Ernst Ulrich-Petersmann, 'Challenges to the Legitimacy and Efficiency of the World Trading System: Democratic Governance and Competition Culture in the WTO' (2004) 7(3) Journal of International Economic Law 585; Rahul Sing, 'The World Trade Organization and Legitimacy: Evolving a Framework for Bridging the Democratic Deficit' (2008) 42(2) Journal of World Trade 347; cf Robert A Dahl, 'Can International Organizations be Democratic? A Skeptic's View' in Ian Shapiro and Casiano Hacker-Cordón (eds), Democracy's Edges (1999) 19.

132 Hurd, above n 76, 71.

${ }^{133}$ See, e.g., Denis J Galligan, 'Procedural Fairness' in Peter Birks (ed), The Frontiers of Liability (1994) vol I, 114 and 116, referring to Bentham's theories on procedure ('The role of procedures is to ensure that the law is applied accurately and, as a consequence, that the social good is realized').
} 
Substantive legitimacy, by contrast, is more directly interested in the aim served by the object of legitimation. Ernst Haas proposes a clearly substantive form of legitimacy when he claims that '[o]rganizational legitimacy exists when the membership values the organization and generally implements collective decisions because they are seen to implement the members' values'.134 The archetypal form of substantive legitimacy is concerned with justice (or substantive fairness), ${ }^{135}$ but it is also reflected in work that seeks to critique or justify given rules or institutions on the basis of human rights, ${ }^{136}$ development, ${ }^{137}$ global welfare ${ }^{138}$ or indeed trade liberalisation.

A similar but separate distinction is drawn between input and output based forms of legitimacy. The input/output distinction was developed by Fritz Scharpf in the context of analysing the 'democratic deficit' in the EU.139 Input-oriented legitimacy, for Scharpf, refers specifically to the concept of 'government by the people. ${ }^{140}$ It is identity-based, and emphasises norms of participation and consensus. Output legitimacy instead refers to 'government for the people', which 'derives legitimacy from its capacity to solve problems requiring collective solutions' that are unable to be solved via individual action, market exchanges or voluntary cooperation. ${ }^{141} \mathrm{It}$ is more interest-based, and emphasises mechanisms of expertise and accountability.

Other writers have adopted the terminology of input and output legitimacy but expanded it beyond the democratic context, ${ }^{142}$ such that input legitimacy includes all procedural and substantive considerations that form part of a decisionmaking process, while output legitimacy includes any form of legitimacy that is validated on the basis of the practical consequences of such decision-making. ${ }^{143}$

${ }^{134}$ Ernst Haas, When Knowledge is Power: Three Models of Change in International Organizations (1990) 87.

135 Allen Buchanan, for instance, argues for understanding legitimacy as being very closely linked to justice when assessing the legitimacy of international institutions. Although he does claim that the concepts are analytically distinct, he distinguishes them only inasmuch as '[j] ustice is an ideal standard, whereas legitimacy expresses a threshold value, in a non-ideal world, for the conditions under which an institution has the right to rule': Buchanan and Keohane, above n 23, 34. See also Allen Buchanan, Justice, Legitimacy and Self-Determination: Moral Foundations for International Law (2004), and Abram Chayes and Antonia Handler Chayes, The New Sovereignty: Compliance with International Regulatory Agreements (1998) 133-4.

136 See, e.g., Ernst-Ulrich Petersmann, 'The WTO Constitution and Human Rights' (2000) 3(1) Journal of International Economic Law 19.

137 See, e.g., Michael Fakhri, 'Reconstruing the WTO Legitimacy Debates towards Notions of Development' (2009) CLPE Research Paper No 45/2009, available at <ssrn.com/abstract=1500562>.

138 See Thomas Cottier, 'The Legitimacy of WTO Law' (2008) NCCR TRADE Working Paper Working Paper No 2008/19, available at <http://phase1.nccr-trade.org/images/stories/publications/IP2/ The_Legitimacy_of_WTO_Law_cottier_final $\% 200808 . p d f>9$.

139 See generally Scharpf, Governing in Europe, above n Error! Bookmark not defined.

140 Ibid, 6.

141 Ibid, 11.

142 Keohane and Nye, above n 122; Kelly, above n Error! Bookmark not defined., 608.

143 Ian Hurd maps Scharpf's input legitimacy onto procedural legitimacy, and output legitimacy to substantive outcomes (Hurd, above n 76, 66-7), but then criticises the distinction for 'gloss[ing] over important distinctions within the categories', favouring a tripartite division between 'favourable outcomes', 'fairness', and 'correct procedure'. However Scharpf's formulation of input legitimacy does not need to be read as purely procedural, being strongly concerned with the promotion of popular 
This broader understanding of output legitimacy is sometimes characterised as outcome-based, or effectiveness-based, legitimacy. ${ }^{144}$ Outcome-based legitimacy judges the object seeking legitimation in terms of a given set of outcomes that are considered desirable. For Scharpf, this is 'government for the people'. Victor Bekkers and Arthur Edwards, continuing in this mode, point to several commonly pursued outcome categories, including government effectiveness, efficiency and responsiveness. ${ }^{145}$ Franck, in describing work focused on outcomes-based legitimacy, notes that writers in this tradition claim that 'a system seeking to validate itself - and its commands - must be defensible in terms of the equality, fairness, justice and freedom which a realized by those commands'. ${ }^{146}$ For the WTO, for instance, it is arguable that much of its moral and social legitimacy (such as it is) derives from the claims that its rules have successfully increased global welfare through reducing trade barriers. The boundaries of outcome-based legitimacy are occasionally blurred by a failure to distinguish between legitimacy based on actual, measurable outcomes and legitimacy based on potential outcomes.

\section{LEGITIMACY DISTINGUISHED}

Much of the appeal of legitimacy as a concept derives from its ability to explain reasons for action - why the ruled obey the rulers, and why the rulers expend their energy on various symbolic and ritualistic efforts to consolidate their authority. ${ }^{147}$ Yet obedience and ritual may also be traced to several other sources, including coercion, self-interest and habit. Differentiating between social legitimacy and these alternative reasons for action highlights the independent analytical and social value of legitimacy. ${ }^{148}$ Careful differentiation of these factors

sovereignty and self-government as values in themselves. Victor Bekkers and Arthur Edwards characterise input legitimacy as largely being concerned with "the normative idea of "government by the people", relating to norms of quality of representation, participation and openness. Bekkers places the procedural aspect of input legitimacy into another category, that of 'throughput legitimacy', which is 'defined in terms of certain qualities of the rules and procedures by which binding decisions are made', including the quality of participation, the quality of checks and balances, and the mechanisms for collective decision making: Victor Bekkers and Arthur Edwards, 'Legitimacy and Democracy: A Conceptual Framework for Assessing Governance Practices' in Victor Bekkers et al (eds), Governance and the Democratic Deficit: Assessing the Democratic Legitimacy of Governance Practices (2007) 35, 44-5.

144 Franck described outcome based legitimacy as the favoured category of 'neo-Marxist philosophers and related students of radical social restructuring [...] In this view, a system seeking to validate itself — and its commands - must be defensible in terms of the equality, fairness, justice and freedom which are realized by those commands': Franck, The Power of Legitimacy among Nations, above n 7, 18. See also Wolfrum, above n 33, 7 .

145 Bekkers, above n 143, 45.

146 Franck, The Power of Legitimacy among Nations, above n 7, 18.

147 See Barker, above n 93.

148 See Patrizia Nanz and Jens Steffek, 'Global Governance, Participation and the Public Sphere' (2004) 39 Government and Opposition 314; Elsig, above n 9, 80; Friedrich Kratochwil, 'The Force of Prescriptions' (1984) 38 International Organization 685. See also Weber: 'But custom, personal advantage, purely affectual or ideal motives of solidarity, do not form a sufficiently reliable basis for a given 
also helps to reinforce the important difference between legitimacy and compliance, and provides some protection against the charge that "legitimacy is indifferent to the conditions of its existence: fear, desire, manipulation, whatever'. ${ }^{149}$

\section{A Legitimacy vs Coercion}

Coercion may be defined as what occurs when one actor causes another to act against their will, usually by the application or threat of harm to that actor or something/one that they value. ${ }^{150}$ The motivation here is not one of belief, incentive or persuasion, but rather one of fear. ${ }^{151}$ Coercion is distinct from legitimacy in that it forces obedience even when a subject does not believe such obedience to be normatively justified. Both motivations can, however, act in tandem. Indeed, a significant portion of the legitimacy literature focuses on precisely this point, treating legitimacy as concerned with the justification of specifically coercive power. ${ }^{152}$ Even now, much of the literature relating legitimacy and international law is expressly concerned with the legitimate use of force across state boundaries. ${ }^{153}$

John Austin and several subsequent generations of legal positivists based the law's obligatory power on coercion (as manifested through sanctions). For Austin, only those orders capable of enforcement via centralised coercion deserved the designation of 'legal' order. He proposed a chain of positive legal legitimacy that was ultimately held to rest not on any form of belief or moral justification but the mere fact of coercive power. ${ }^{154}$ Austin excluded laws that were not backed by sanction from law 'properly so called' and dismissed them as either 'imperfect laws'155 or 'positive morality', thereby lacking in obligatory character. ${ }^{156}$ Coercion

domination. In addition there is normally a further element, the belief in legitimacy. Experience shows that in no instance does domination voluntarily limit itself to the appeal to material or affectual or ideal motives as a basis for its continuance. In addition every such system attempts to establish and cultivate a belief in its legitimacy': Weber, Economy and Society, above n 79, 213.

149 Koskenniemi, 'Miserable Comforters', above n 10, 409.

${ }^{150}$ For a more detailed account, see Robert Nozick, 'Coercion' in Sidney Morgenbesser, Patrick Suppes, and Morton White (eds), Philosophy, Science, and Method: Essays in Honor of Ernest Nagel (1969) 440; Scott Anderson, 'Coercion' (10 February 2006) in Stanford Encyclopedia of Philosophy at $<$ http://plato.stanford.edu/entries/coercion>.

${ }^{151}$ See Hurd, above n 76, 35.

152 See, e.g., Arthur Ripstein, 'Authority and Coercion' (2004) 32(1) Philosophy and Public Affairs 2. Weber defined the state as 'the form of human community which (successfully) lays claim to the monopoly of legitimate physical violence within a particular territory': Max Weber, 'Politics as a Vocation' in Max Weber, The Vocation Lectures (Rodney Livingstone trans, 2004) 32, 33.

153 See David Armstrong, Theo Farrell and Bice Maiguashca (eds), Force and Legitimacy in World Politics (2006); Richard Falk, Mark Juergensmeyer and Vesselin Popovski (eds), Legality and Legitimacy in Global Affairs (2012) Part Two.

154 Except for the moment of identification of the sovereign, who could be recognised as enjoying the habitual obedience of the population: John Austin, The Province of Jurisprudence Determined (1853) Lecture 1.

155 Ibid, 27-8.

156 Ibid, 11-12. 
could thus be considered to cover the field when it came to evaluating reasons for compliance with the law, which would make the study of legitimacy redundant. Austin thus separated the validity of a legal order from its acceptance by a population. Even if this approach were to be adopted, it would not provide a reason for ignoring legitimacy in relation to international law, which Austin included in the category of 'positive morality'. Franck highlights that it is this very exclusion of international law from systematised coercion that makes it such a fruitful subject for the study of legitimacy. ${ }^{157}$

Kelsen also defined law as a normative coercive order. Although he recognised the psychological internalisation of legal norms by individuals norms could '[become] the product of a man's consciousness' - he did not recognise this as leading to independent reasons for action beyond coercion. Kelsen did, however, distinguish between different forms of coercion, recognising psychological coercion as well as coercion in the form of sanctions. He was thus able to generate the apparent paradox that ' $[\mathrm{v}]$ oluntary obedience is itself a form of motivation, that is, of coercion, and hence is not freedom, but it is coercion in the psychological sense'. ${ }^{158}$

Hart, in criticising and building on Austin's theories, moved the debate on from simple coercion. On the one hand, he highlighted that not all laws are coercive in nature. 159 There are laws that are followed for reasons other than the threat of sanction. Hart also illustrated that it was not enough for commands backed by coercive sanction to constitute a legal order. There must be some other factor that allows us to accept the coercion backing a legal order but not the coercive threats of, say, a gun-wielding bank robber. For Hart, the determinative mechanism was the rule of recognition - the founding social fact of legal legitimacy. Moving even further, Leslie Green argues that in contemporary legal systems coercion provides only a secondary motivation for obedience and support, as a mere 'reinforcing motivation when the political order fails in its primary normative technique of authoritative guidance'. ${ }^{160}$

\section{B LEgITIMACY VS SELF-INTEREST}

Self-interest ${ }^{161}$ provides a third reason for action, based on the calculation of personal advantage. Self-interest is much favoured by international relations realists, ${ }^{162}$ who often ignore the effect of international norms on state behaviour. The narrow approach tends to treat actors as profoundly egoistic and tends to

\footnotetext{
${ }^{157}$ Franck, The Power of Legitimacy among Nations, above n 7, 19.

158 Kelsen, General Theory of Law and State, above n 35, 18-20.

159 Contrasting coercive laws with facilitative laws such as those governing contract or marriage: Hart, above n 37, 27-33.

160 Leslie Green, The Authority of the State (1988) 75.

161 See also Weber's discussion of 'expediency' in Weber, Economy and Society, above n 79, 37.

162 Hurd, above n 76, 37.
} 
focus on material interests. ${ }^{163}$ The idea is that individuals and states make decisions as to whether to obey or support norms, actions or institutions based on 'an instrumental and calculated assessment of the net benefits of compliance versus noncompliance, with an instrumental attitude toward social structures and other people'. ${ }^{164}$ One of the clearest articulations of this position in international law comes from Jack Goldsmith and Eric Posner, who argue that international law does not pull states toward compliance contrary to their interests, and the possibilities for what international law can achieve are limited by the configurations of state interests and the distribution of state power'. ${ }^{165}$

Ian Hurd describes the key difference between self-interest and coercion as lying in their different outcomes. The application of coercion leaves an actor worse off than previously, whereas the application of self-interest leaves an actor better off. Moreover, Hurd distinguishes between self-interest and legitimacy by analogy to the distinction between interest and self-interest. Although legitimacy can be understood to encapsulate a set of interests, self-interest assumes a narrowly egoistic attitude on the part of the relevant actor. ${ }^{166}$ The self-interested actor ignores normative structures in favour of maximally improving its own situation 'de novo at each decision point'. ${ }^{167}$ Self-interest therefore represents a narrowly instrumentalist view which dismisses the relevance of the interests of a broader community.

As with coercion, legitimacy has a dual relationship to self-interest. On the one hand it provides a parallel — occasionally complementary, occasionally competing ${ }^{168}$ - reason for action. On the other hand, it provides a framework for analysing how interests come to be seen as self-interests. ${ }^{169}$ Beyond the basic

163 See, e.g., Weber: 'Purely material interests and calculations of advantages as the basis of solidarity between the chief and his administrative staff result, in this as in other connexions, in a relatively unstable situation': Weber, Economy and Society, above n 79, 213. See also Steffek, above n 103, 6. Cf Jack L Goldsmith and Eric A Posner, The Limits of International Law (2005) who include reputational interests as part of a game theoretical approach to understanding order in international relations. They nonetheless express concern that 'scholars sometimes lean too heavily on a state's reputational concern for complying with international law': at 102 (emphasis omitted).

164 Hurd, above n 76, 37

165 Goldsmith and Posner, above n 163, 13. Cf Anne van Aaken, 'To Do Away with International Law? Some Limits to "The Limits of International Law" (2006) 17 European Journal of International Law 289.

166 Ibid, 38, citing Christopher Jencks, 'Varieties of Altruism' in Jane J Marsbridge (ed), Beyond Self-Interest (1990) 53 and Alexander Wendt, A Social Theory of International Politics (1999).

167 Ibid, 39.

168 Daniel Bodansky argues that 'self-interest cross-cuts the distinction [...] between rational persuasion, power, and legitimacy. As Professor Keohane noted, one of the reasons why states might agree to subject themselves to the authority of an international institution, and consider its authority legitimate, is that they think such institutions are in their self-interest': Daniel Bodansky, 'The Concept of Legitimacy in International Law' in Rüdiger Wolfrum and Volker Röben, Legitimacy in International Law (2008) 309, 312, referring to Robert Keohane's comments in 'Discussion Following Presentations by Rüdiger Wolfrum, Robert Keohane, Alain Pellet and Anthony D'Amato' in Rüdiger Wolfrum and Volker Röben, Legitimacy in International Law (2008) 93, 104. Steffek notes that 'Franck runs into conceptual difficulties when he introduces state interests to explain compliance pull of rules, rather than sticking to rule-inherent factors' (citation omitted): Steffek, above n 103, 4, fn 4.

169 See Alexander Wendt, Social Theory of International Politics (1999) 92-138 ('the content of interests are in turn constituted in important part by ideas: at 135). 
necessities of survival (and not always then), there is nothing inevitable about what is conceived of as self-interest. Is it better to be materially rich in life, or to follow a moral code prohibiting riches which nonetheless guarantees a blissful afterlife? Does following IMF requirements necessarily result in the best economic outcomes, or are there other worthwhile ways to restructure an economy to serve human interests? Legitimacy provides a vocabulary for exploring who gets to make the decisions about what lies in an individual or state's self-interest. Self-interest, conversely, may also affect the extent to which people perceive a rule, ruler or system as morally legitimate. A continued failure to satisfy the self-interests of a large enough community will invariably suggest a failure of outcome legitimacy and spark a reconsideration of existing processes. ${ }^{170}$ Having increased legitimacy may serve a ruler's self-interests, and is easier to sustain if the ruled think that the relationship of rule is in their self-interests. Either alone is much less effective at maintaining stability and obedience over time.

\section{C}

\section{LEGITIMACY Vs HABIT}

A fourth reason for action is that of habit. Although addressed by Weber, ${ }^{171}$ habit has received less attention in the more recent writings on legitimacy. The ideas of coercion, self-interest and legitimacy discussed above all assume a level of conscious reflection about a given subject's reasons for action. Yet, as Weber notes, ' $[\mathrm{i}] \mathrm{n}$ the great majority of cases actual action goes on in a state of inarticulate half-consciousness or actual unconsciousness of its subjective meaning. ${ }^{172}$ Consequently, much of the time actors take actions not on the basis of conscious fear, or moral rectitude, or the promise of material gain, but simply out of unreflective habit. This may be justified by the understanding of habit as involving the unthinking extension of an initial conscious reason for acquiescence. The possibility of any of legitimacy, self-interest, or coercion forming the basis for habit, however, highlights the danger in inferring social legitimacy from mere public acquiescence to authority. ${ }^{173}$

\footnotetext{
170 Beetham echoes Hart's gunman metaphor in this context: 'To explain all action conforming to rules as the product of a self-interested calculation of the consequences of breaching them, it to elevate the attributes of the criminal into the standard for the whole of humankind': Beetham, above n 27, 27.

171 Weber notes that ' $[\mathrm{s}]$ trictly traditional behaviour [...] lies very close to the borderline of what can justifiably be called meaningfully oriented action, and indeed often on the other side': Weber, Economy and Society, above n 79, 25 and 29. The border between the two is particularly blurry in the case of legitimacy based on tradition, in which the way things are done is legitimated because that is the way that things have been done before.

$172 \mathrm{Ibid}, 21$. Habit is not the same thing as legitimacy based on custom, or tradition, which involves the conscious formulation of a belief that a thing is normatively justified based on the inherent value of custom or tradition.

173 Rosemary O’Kane, 'Against Legitimacy' (1993) XLI Political Studies 471, 475-6.
} 


\section{CONCLUSION}

This paper has attempted to clarify some of the distinctions between the different senses in which 'legitimacy' has been used and the relevance of the concept to international law. Questions about legitimacy may be understood as questions about the justificatory frameworks behind the expansion, contraction, formation, transformation, maintenance and dissolution of legal orders. That the word legitimacy has been used indiscriminately and ambiguously by various actors is no argument against its utility, or potential for analytical clarity. If it were, it would also be necessary to throw out any number of other concepts ranging from justice, to equality, to freedom. As one of the prime motivators for international action, alongside coercion, self-interest and habit, it occupies a central position in our understandings of the stability and effectiveness of legal regimes. It can also point the way to more fundamental questions about why those regimes may or may not be worthy of support. Moreover, international lawyers can make distinctive contributions to legitimacy debates, bringing to bear a complex understanding of law and its attendant values that might otherwise be ignored. That the insights deriving from legitimacy scholarship are spreading to international law should be celebrated, not condemned. 